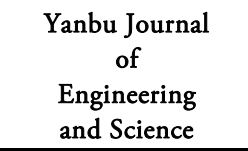

ISSN: $1658-5321$
Vol. 1, October $2010(1431 \mathrm{H})$

www.yic.edu.sa/yjes

\title{
THERMO-ECONOMICS ANALYSIS OF GAS TURBINES POWER PLANTS WITH COOLED AIR INTAKE
}

\author{
Rahim K. Jassim ${ }^{1}$, Galal M. Zaki ${ }^{2}$ and Majed M. Alhazmy ${ }^{2}$ \\ ${ }^{1}$ Department of Mechanical Engineering Technology, Yanbu Industrial College, \\ P. O. Box 30436, Yanbu Al-Sinaiyah, Kingdom of Saudi Arabia, \\ Email: rkjassim@yahoo.com \\ ${ }^{2}$ Department of Thermal Engineering and Desalination Technology, King Abdulaziz University, \\ P. O. Box 80204, Jeddah 21 587, Saudi Arabia \\ Email: gzaki@kau.edu.sa,mhazmy@kau.edu.sa
}

\begin{abstract}
Gas turbine (GT) power plants operating in arid climates suffer a decrease in output power during the hot summer months because of insufficient cooling. Cooling the air intake to the compressor has been widely used to mitigate this shortcoming. An energy analysis of a GT Brayton cycle coupled to a refrigeration cycle shows a promise for increasing the output power with a little decrease in thermal efficiency. A thermoeconomics algorithm is developed and applied to an open cycle, Hitachi MS700 GT plant at the industrial city of Yanbu (Latitude $24^{\circ} 05^{\prime \prime} \mathrm{N}$ and longitude $38^{\circ} \mathrm{E}$ ) by the Red Sea in the Kingdom of Saudi Arabia. Result shows that the enhancement in output power depends on the degree of chilling the air intake to the compressor (a 12 - $22 \mathrm{~K}$ decrease is achieved). For this case study, maximum power gain ratio (PGR) is $15.46 \%$, at a decrease in thermal efficiency of $12.25 \%$. The cost of adding the air cooling system is also investigated and a cost function is derived that incorporates time-dependent meteorological data, operation characteristics of the GT and the air intake cooling system and other relevant parameters such as interest rate, lifetime, and operation and maintenance costs. The profit of adding the air cooling system is calculated for different electricity tariff.
\end{abstract}

KEYWORDS: gas turbine; power boosting; hot climate; air cooling; water chiller.

\section{INTRODUCTION}

During hot summer months, the demand for electricity increases and utilities may experience difficulty meeting the peak loads, unless they have sufficient reserves. In all Gulf States, where the weather is fairly hot year around, air conditioning is a driving factor for electricity demand and operation schedules. In the Kingdom of Saudi Arabia (KSA) the utilities employ gas turbine (GT) power plants (present capacity $14 \mathrm{GW}$ ) to meet the A/C peak load. Unfortunately, the power output and thermal efficiency of GT plants decrease in the summer because of the increase in the compressor power. The lighter hot air at the GT intake decreases the mass flow rate and in turn the net output power. For an ideal GT open cycle, the decrease in the net output power is $1 \%$ for every $1.6{ }^{\circ} \mathrm{C}$ increase in the ambient air temperature

Received, April 2, 2010; accepted June 30, 2010 
Elliot [1]. To overcome this problem, cooling methods of the air intake, such as evaporative and/or refrigeration has been widely considered and implemented.

Cooling methods of the air intake can be classified into direct (e.g. evaporative cooling) and indirect (e.g., refrigeration). In the direct method of evaporative cooling, the air intake cools off by contacts with a cooling fluid, such as atomized water sprays, fog or a combination of both (Cortes [2], Wang [3]). Evaporative cooling has been extensively studied and successfully implemented for cooling the air intake in GT power plants in dry and hot regions (Ameri et al. [4], [5], Johnson [6], Alhazmy [7-8]). This cooling method is not only simple and inexpensive, but the water spray also reduces the NOx content in the exhaust gases. This may also cause unburned fuel or soot emissions. In addition, the need for a water treatment plant in such a case to avoid damage to the subsequent compressor and turbine components might be needed. Recently, Sanaye and Tahani [9] investigated the effect of using a fog cooling system, with 1 and $2 \%$ over-spray, on the performance of a combined GT; they reported an improvement in the overall cycle heat rate for several GT models.

Although evaporative cooling systems have low capital and operation cost, reliable and require moderate maintenance, they have low operation efficiency, consume large quantities of water and the impact of the non evaporated water droplets in the air stream could damage the compressor blades (Tillman et al. [10]). The water droplets carryover and the resulting damage to the compressor blades, is a primary reason for limiting the uses of evaporative cooling, which also less efficient in the humid coastal areas. In these areas, the air could not be cooled below the wet bulb temperature (WBT). Chaker et al. [11-13], Homji-meher et al. [14] and Gajjar et al. [15] have presented results of extensive theoretical and experimental studies covering aspects of fogging flow thermodynamics, droplets evaporation, atomizing nozzles design and selection of spray systems as well as experimental data on testing systems for gas turbines up to $655 \mathrm{MW}$ in combined cycle plant.

In the indirect mechanical refrigeration cooling approach the constraint of humidity is eliminated and the air temperature can be reduced well below the ambient WBT. The mechanical refrigeration cooling has gained popularity over the evaporative method and in KSA, for example, 32 GT units have been outfitted with mechanical air chilling systems. There are two approaches for mechanical air cooling; either using vapor compression (Alhazmy [8] and Elliott [1] or absorption refrigerator machines (Yang et al. [16], Ondryas et al. [17], Punwani [18] and Kakarus et al. [19]). In general, application of the mechanical air-cooling increases the net power but in the same time reduces the thermal efficiency. For example, Alhazmy et al. [7] showed that for a GT of pressure ratio 8 cooling the intake air from $50^{\circ} \mathrm{C}$ to $40^{\circ} \mathrm{C}$ increases the power by $3.85 \%$ and reduces the thermal efficiency by $1.037 \%$. Stewart and Patrick [20] raised another disadvantage (for extensive air chilling) concerning ice formation either as ice crystals in the chilled air or as solidified layer on entrance surfaces.

Recently, alternative cooling methods have been investigated. Farzaneh-Gord and DeymiDashtebayaz [21] proposed using a reversed Brayton refrigeration cycle for cooling the air intake for GT and improve the refinery gas turbines performance using the cooling capacity of the refinery natural-gas pressure drop station (Zaki et al. [22]). They reported an increase in the output power up to $20 \%$, 
but a $6 \%$ decrease in thermal efficiency. This analysis was extended by Jassim et al. [23] to include the exergy analysis and show the maximum improvement is $14.66 \%$ due the components irreversibilities. Khan et al. [24] analyzed a system in which the turbine exhaust gases are cooled and fed back to the compressor inlet with water harvested from the combustion products. Erickson [25-26] suggested using a combination of a waste heat driven, absorption air cooling with water injection into the combustion air; the concept is named the "power fogger cycle". The motivation for mounting a GT cooling system is either to maximize the net power output or operate close to the standard ISO inlet air temperature, which means operating close to the maximum thermal efficiency.

Thermal analyses of GT cooling are abundant in the literature, but a few investigations considered the economics of the cooling process. A sound economic evaluation of implementing an air intake, GT cooling system is quite involved. Such an evaluation should account for the variations in the ambient conditions (temperature and relative humidity) and the fluctuations in the fuel and electricity prices and the interest rates. Therefore, the selection of a cooling technology (evaporative or refrigeration) and the sizing out of the equipment should not be based solely on the results of a thermal analysis but should include estimates of the cash flow. Gareta et al. [27] has developed a methodology for combined cycle GT that calculated the additional power gain for 12 months and the economic feasibility of the cooling method. From an economical point of view, they provided straight forward information that supported equipment sizing and selection. Chaker et al. [13] have studied the economical potential of using evaporative cooling for GTs in USA, while Hasnain [28] examined the use of using ice storage methods for GTs' air cooling in KSA. Yang et al. [16] presented an analytical method for evaluating a cooling technology of a combined cycle GT that included parameters such as the interest rate, payback period and the efficiency ratio for off-design conditions of both the GT and cooling system. Investigations of evaporative cooling and steam absorption machines showed that inlet fogging is superior in efficiency up to intake temperatures of 15$20^{\circ} \mathrm{C}$, though it results in a smaller profit than inlet chilling (Yang et al. [16]).

In the present study, the performance of a cooling system that consists of a chilled water external loop coupled to the GT entrance is investigated. The analysis that accounts for the changes in the thermodynamics parameters as well as the economic variables such as profitability and cash flow and the life time of the system, is extended to cooling components such as chiller, water pumps and the heat transfer cooling coil. An objective of the present study is to assess the importance of using a coupled thermo-economics analysis in the selections of the cooling system and operation parameters.

The developed thermo-economics algorithm is applied to an open cycle, Hitachi MS700 GT plant at the industrial city of Yanbu (Latitude $24^{\circ} 05^{\prime \prime} \mathrm{N}$ and longitude $38^{\circ} \mathrm{E}$ ) by the Red Sea in the Kingdom of Saudi Arabia. Finally, the cost analysis which is based on $10 \%$ interest rate and three years payback period of the water chiller is presented to determine the economic feasibility of using water chiller as an air cooler. 


\section{THERMODYNAMICS ANALYSIS}

Fig. 1.a shows a schematic of a simple open GT "Brayton cycle" coupled to a refrigeration system. The power cycle consists of a compressor, combustion chamber and a turbine. It is presented by states 1-2-3-4 on the T-s diagram, Fig. 1.b. The cooling system consists of a refrigerant compressor, air cooled condenser, throttle valve and an evaporator. The chilled water from the evaporator passes through a cooling coil mounted at the air compressor entrance, Fig. 1.a. The refrigeration cycle is presented in the $\mathrm{T}$-s diagram, Fig. 1.c by states $a, b, c$ and $d$. A fraction of the electricity produced by the turbine is used to power the refrigerant compressor and the chilled water pumps, as indicated by the dotted lines in Fig. 1.a. To investigate the performance of the coupled GT-cooling system the different cycles involved are analyzed.

\subsection{GAS TURBINE CYCLE ANALYSIS}

As seen in Figures 1.a and 1.b, the processes $1-2 s$ and $3-4 s$ are isentropic. Assuming air behaves as a perfect gas, then the temperatures and pressures are related to the pressure ratio, PR, by:

$$
\frac{T_{2 s}}{T_{1}}=\frac{T_{3}}{T_{4 s}}=\left[\frac{P_{2}}{P_{1}}\right]^{\frac{k-1}{k}}=P R^{\frac{k-1}{k}}
$$

Where, $k$ is the isentropic index.

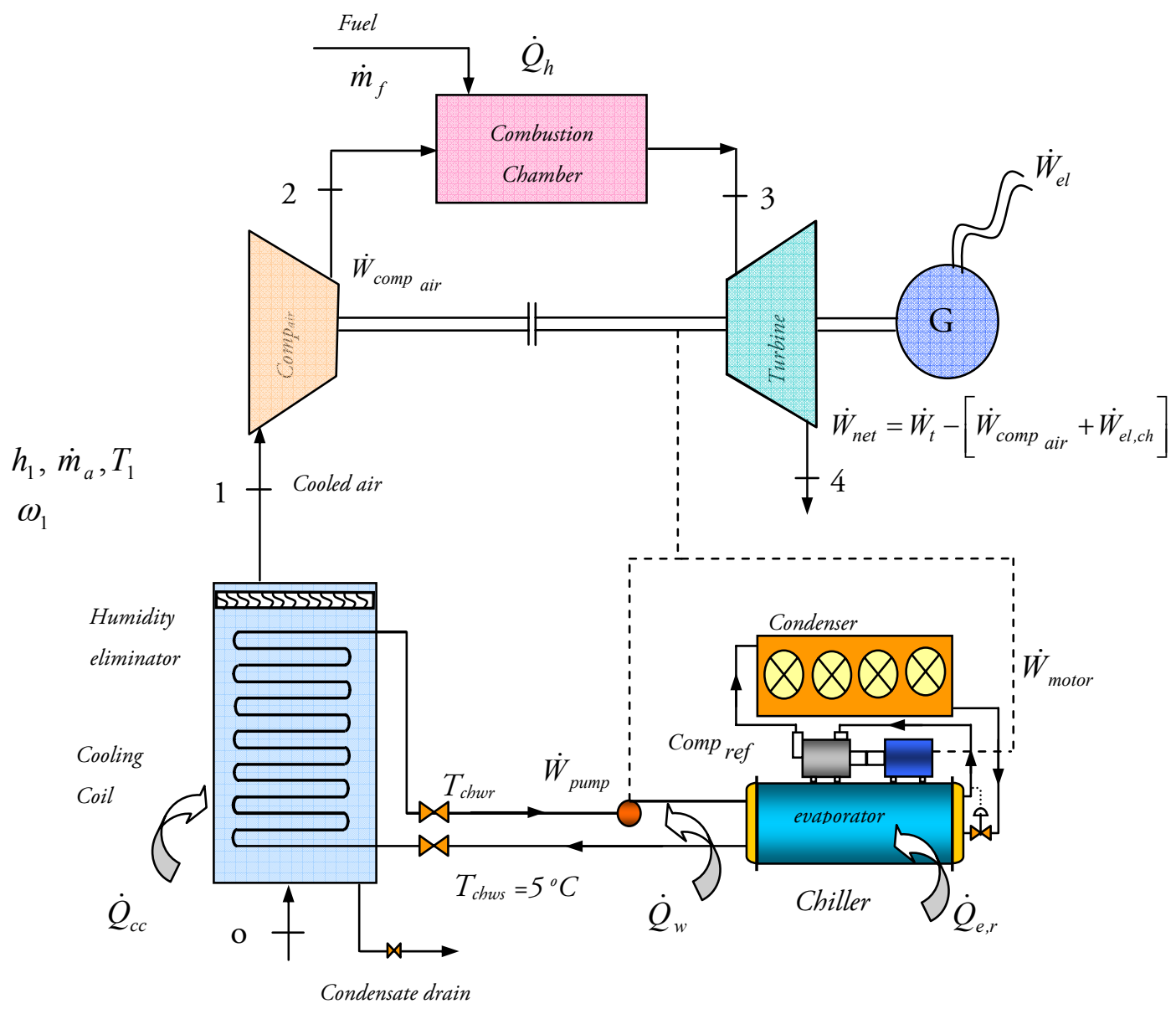

Fig. 1.a. Simple open type gas turbine with a chilled air-cooling unit 
The net power output of the GT with the mechanical cooling system, Fig. 1.a. is given as:

$$
\dot{W}_{n e t}=\dot{W}_{t}-\left(\dot{W}_{c o m p}+\dot{W}_{e l, c h}\right)
$$

The first term of the RHS is the power produced by the turbine due to expansion of hot gases of mass flow rate $\dot{m}_{t}$ as;

$$
\dot{W}_{t}=\dot{m}_{t} c_{p g} \eta_{t}\left(T_{3}-T_{4 s}\right) \text {. }
$$

In this equation, $\dot{m}_{t}$ is the total gases mass flow rate from the combustion chamber given in terms of the fuel air ratio $f=\dot{m}_{f} / \dot{m}_{a}$, and the air humidity ratio at the compressor intake $\omega_{1}$, (kgw/kgdry air) at state 1 (Fig. 1.a) as;

$\dot{m}_{t}=\dot{m}_{a}+\dot{m}_{v}+\dot{m}_{f=} \dot{m}_{a}\left(1+\omega_{1}+f\right)$

The compression power for the humid air between states 1 and 2, Fig. 1.a, is estimated from:

$$
\dot{W}_{\text {comp }}=\dot{m}_{a} c_{p a}\left(T_{2}-T_{1}\right)+\dot{m}_{v}\left(h_{v 2}-h_{v 1}\right)
$$

where $h_{\mathrm{v} 2}$ and $h_{\mathrm{v} 1}$ are the enthalpies of saturated water vapor at the compressor exit and inlet states respectively, $\dot{m}_{v}$ is the mass of water vapor $=\dot{m}_{a} \omega_{1}$.

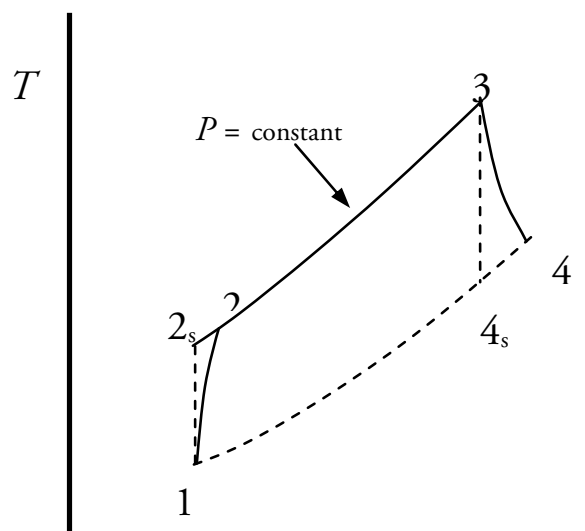

$s$

Fig. 1.b. T-s diagram of an open type gas turbine cycle

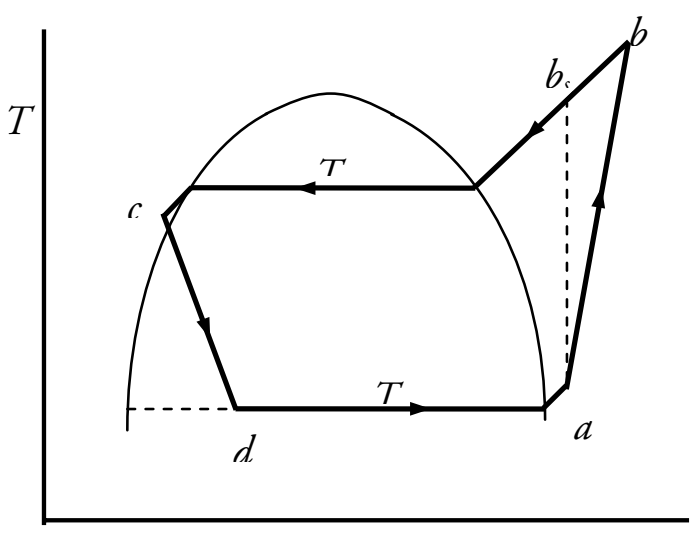

$S$

Fig. 1.c. T-s diagram for a refrigeration machine

The last term in Eq. $2\left(\dot{W}_{e l, c h}\right)$ is the power consumed by the cooling unit for driving the refrigeration machine electric motor, pumps and auxiliaries. The thermal efficiency of a GT coupled to an air cooling system is then;

$\eta_{c y}=\frac{\dot{W}_{t}-\left(\dot{W}_{c o m p}+\dot{W}_{e l, c h}\right)}{\dot{Q}_{h}}$

Substituting for T4s and $\dot{m}_{t}$ from Equations (1) and (4) into Eq. (3) yields:

$\dot{W}_{t}=\dot{m}_{a}\left(1+\omega_{1}+f\right) c_{p g} \eta_{t} T_{3}\left(1-\frac{1}{P R^{\frac{k-1}{k}}}\right)$

The turbine isentropic efficiency, $\eta_{t}$, can be estimated using the practical relation recommended by Alhazmy [7] as:

$\eta_{t}=1-\left(0.03+\frac{P R-1}{180}\right)$

Relating the compressor isentropic efficiency to the changes in temperature of the dry air and assuming that the compression of water vapor behaves as a perfect gas; the actual compressor power becomes;

$\dot{W}_{\text {comp }_{a i r}}=\dot{m}_{a}\left[c_{p a} \frac{\mathrm{T}_{1}}{\eta_{\mathrm{c}}}\left(P R^{\frac{k-1}{k}}-1\right)+\omega_{1}\left(h_{v 2}-h_{v 1}\right)\right]_{(9)}$ 
The compression efficiency, $\eta_{c}$, can be evaluated using the following empirical relation, Alhazmy [7];

$$
\eta_{c}=1-\left(0.04+\frac{P R-1}{150}\right)
$$

The heat balance in the combustion chamber (see Fig. 1.a) gives the heat rate supplied to the gas turbine cycle as:

$$
\begin{gathered}
\dot{Q}_{h}=\dot{m}_{f} N C V \eta_{\text {comb }}=\left(\dot{m}_{a}+\dot{m}_{f}\right) c_{p g} T_{3}- \\
\dot{m}_{a} c_{p a} T_{2}+\dot{m}_{v}\left(h_{v 3}-h_{v 2}\right)
\end{gathered}
$$

Introducing the fuel air ratio $f=\dot{m}_{f} / \dot{m}_{a}$ and substituting for T2 in terms of T1 into Eq.12 yields:

$\dot{Q}_{h}=\dot{m}_{a} T_{l}\left[\begin{array}{l}(1+f) c_{p g} \frac{T_{3}}{T_{l}}- \\ c_{p a}\left(\frac{P R^{\frac{k-1}{k}}-1}{\eta_{c}}+1\right)+\frac{\omega_{I}}{T_{l}}\left(h_{v 3}-h_{v 2}\right)\end{array}\right]$

The simple expression for $f$ is selected here, Alhazmy et al. [8] as:

$f=\frac{c_{p g}\left(T_{3}-298\right)-c_{p a}\left(T_{2}-298\right)+\omega_{1}\left(h_{v 3}-h_{v 2}\right)}{N C V \eta_{\text {comb }}-c_{p g}\left(T_{3}-298\right)}$

In this equation, hv2 and hv3 are the enthalpies of water vapor at the combustion chamber inlet and exit states respectively and can be calculated from Dossat [29]:

$\mathrm{hv}, \mathrm{j}=2501.3+1.8723 \mathrm{Tj} \quad, \mathrm{j}$ refers to states 1 or 3

The four terms of the gas turbine net power and efficiency in Eq. (2) ( $\dot{W}_{t}, \dot{W}_{c o m p}, \dot{W}_{e l, c h}$ and $\dot{Q}_{h}$ ) depend on the air temperature and relative humidity at the compressor inlet whose values are affected by the type and performance of the cooling system.
The chillers' electric power, ${ }^{\text {el,ch }}$ calculations is described below.

\subsection{REFRIGERATION COOLING SYSTEM ANALYSIS}

For the present analysis, the inlet air is cooled using a cooling coil placed at the compressor inlet bell mouth. The chilled water from the refrigeration machine is the heat transport fluid, Fig. 1.a. The chiller's total electrical power can be expressed as the sum of the electric motor power ( $\left.\dot{W}_{\text {motor }}\right)$, the pumps $\left(\dot{W}_{P}\right)$ and auxiliary power for fans and control units, $\left(\dot{W}_{A}\right)$ as:

$\dot{W}_{e l, c h}=\dot{W}_{\text {motor }}+\dot{W}_{P}+\dot{W}_{A}$

In this equation, $\dot{W}_{A}$ is the input power to the auxiliary equipment, such as the condenser fans, control system, etc and is estimated to be between $5 \%$ and $10 \%$ of the compressor power. In the present study, an air cooled condenser is used, and $10 \%$ of the power required to drive the compressor motor is estimated for the cycle auxiliaries $\left(\dot{W}_{A}=0.1 \dot{W}_{\text {motor }}\right)$. The second term in Eq. 16 is the pumping power that is related to the chilled water flow rate and the pressure drop across the cooling coil, so that:

$\dot{W}_{P}=\dot{m}_{c w} v_{f}(\Delta P) / \eta_{\text {pump }}$

The minimum energy utilized by the compressor is that for the isentropic compression process (a-bs), Fig 1.c. The actual chiller power includes losses due to mechanical transmission, inefficiency in the drive motor converting electrical to mechanical energy and the volumetric efficiency, Dossat, [29]. In general the compressor electric motor work is related to the refrigerant enthalpy change as

$\dot{W}_{\text {motor }}=\frac{\dot{m}_{r}\left(h_{b}-h_{a}\right)_{r}}{\eta_{e u}}$ 
The subscript $r$ indicates refrigerant and $\eta_{e u}$ known as the energy use factor, $\eta_{e u}=\eta_{m} \times \eta_{e l} \times \eta_{v o}$. The quantities on the right hand side are the compressor mechanical, electrical and volumetric efficiencies respectively. $\eta_{e u}$ is usually determined by manufacturers and depends on the type of the compressor, the pressure ratio $\left(P_{b} / P_{a}\right)$ and the motor power. For the present analysis $\eta_{e u}$ is assumed $85 \%$.

Cleland et al. [30] developed a semi-empirical form of Equation 18 to calculate the compressor's motor power usage in terms of the temperatures of the evaporator and condenser in the refrigeration cycle, $T_{e}$ and $T_{c}$ respectively as;

$$
\dot{W}_{\text {motor }}=\frac{\dot{m}_{r}\left(h_{a}-h_{d}\right)_{r}}{\frac{T_{e}}{\left(T_{c}-T_{e}\right)}(1-\alpha x)^{n} \eta_{e u}}
$$

In this equation, $\alpha$ is an empirical constant that depends on the type of refrigerant and $\mathrm{x}$ is the quality at state $\mathrm{d}$ in Fig 1.c. The empirical constant is 0.77 for R-22 and 0.69 for R-134a (Cleland et al. [30]. The constant $\mathrm{n}$ depends on the number of the compression stages; for a simple refrigeration cycle with a single stage compressor $\mathrm{n}=1$. The nominator of Eq. 19 is the evaporator capacity, $\dot{Q}_{e, r}$ and the first term of the denominator is the coefficient of performance of an ideal refrigeration cycle operating between $\mathrm{Te}$ and Tc. Equations 2, 5 and 19 could be solved for the power usages by the different components of the coupled GT-refrigeration system and the increase in the power output as function of the air intake conditions. This thermodynamic performance analysis is coupled to a system economic analysis described next.

\section{ECONOMICS ANALYSIS}

The increase in the power output will add to the revenue of the GT plant but will partially offset by the increase the capital cost associated with the installation of the cooling system and the personnel and utility expenditures for the operation of that system. For a cooling system that includes a water chiller, the increase in expenses includes the capital installments for the chiller $\left(C_{c h}^{c}\right)$ and cooling coil $\left(C_{c c}^{c}\right)$ and the annual operational expenses. The latter is a function of the operation period $^{t_{o p}}$ and the electricity rate. If the chiller consumes electrical power $\dot{W}_{e l, c h}$ and the electricity rate is $C_{e l}(\$ / \mathrm{kWh})$ then the total annual expenses can be expressed as:

$C_{\text {total }}(\$ / y)=a^{c}\left[C_{c h}^{c}+C_{c c}^{c}\right]+\int_{0}^{t_{o p}} C_{e l} \dot{W}_{e l, c h} d t$

In this equation, $a^{c}$ is the capital-recovery factor

$a c=\frac{i_{r}\left(1+i_{r}\right)^{n}}{\left(1+i_{r}\right)^{n}-1}$,

which when multiplied by the total investment gives the annual payment to payback the initial investment after a specified period (n).

The chiller's purchase cost may be estimated from venders or mechanical equipment cost index, in which this cost is related to the chiller's capacity, $\dot{Q}_{e, r}(\mathrm{~kW}$ or Ton/day). For a particular chiller size and methods of construction and installation, the capital cost is usually given by manufacturers in the following form;

$C_{c h}^{c}=\alpha_{c h} \times \dot{Q}_{e, r}$

where, $\alpha_{c h}$ is a multiplication cost index in $\$ / \mathrm{kW}$. For simplicity, the maintenance expenses are assumed as a certain fraction $\left({ }^{\alpha_{m}}\right)$ 
of the capital cost of the chiller, therefore, the total chiller capital coast is given as;

$$
C_{c h}^{c}(\$)=\alpha_{c h}\left(1+\alpha_{m}\right) \dot{Q}_{e, r}
$$

Similarly, the capital cost of a particular cooling coil is given by manufacturers in terms of the cooling capacity that is directly proportional to the total heat transfer surface area $\left({ }^{\left.A_{c c} \mathrm{~m} 2\right)}\right.$ Kotas [31] as;

$$
C_{c c}^{c}(\$)=\beta_{c c}\left(A_{c c}\right)^{m}
$$

In this equation, $\beta_{c c}$ and $m$ depend on the type of the cooling coil and material. For the present study and local Saudi market, $\beta_{c c}=$ $30000 \$ / \mathrm{m} 2$ and $m_{=}=0.582$ are recommended (Hameed Zubair, Al Salem York Co consultation [32]). Substituting equations 22 and 23 into Eq. 20, assuming for simplicity that the chiller power is an average constant value but the electricity rate is time independent, the annual total expenses for the cooling system become;

$$
\begin{gathered}
\mathrm{C}_{\text {total }}(\$ / \mathrm{y})=\mathrm{a}^{\mathrm{c}}\left[\alpha_{\mathrm{ch}}\left(1+\alpha_{\mathrm{m}}\right) \dot{\mathrm{Q}}_{\mathrm{e}, \mathrm{r}}+\beta_{\mathrm{cc}}\left(\mathrm{A}_{\mathrm{cc}}\right)^{\mathrm{m}}\right)+ \\
\mathrm{t}_{\mathrm{op}} \mathrm{C}_{\mathrm{el}} \dot{\mathrm{W}}_{\mathrm{el}, \mathrm{ch}}
\end{gathered}
$$

In Eq. 24, the heat transfer area, $A_{c c}$, is used to evaluate the cost of the cooling coil. An energy balance for both the cooling coil and the refrigerant evaporator, taking into account the effectiveness factors for the evaporator, $\varepsilon_{\text {eff }, e r}$, and the cooling coil, ${ }_{\text {eff }, c c}$, gives

$$
A_{c c}=\frac{\dot{Q}_{c c}}{U \Delta T_{m} F}=\frac{\dot{Q}_{e, r} \times \varepsilon_{e f f, e r} \times \varepsilon_{e f f, c c}}{U \Delta T_{m} F}
$$

Where, $U$ is the overall heat transfer coefficient for the chilled water-air tube bank heat exchanger. Gareta, et al. [27] suggested a moderate value of $64 \mathrm{~W} / \mathrm{m} 2 \mathrm{~K}$. The correction factor $\mathrm{F}$ is 0.98 as recommended by Gareta et al. [27].

In reference to Fig. 2, showing the different temperatures in the combined refrigerant, water chiller and air cooling system, the mean temperature difference for the cooling coil (air and chilled water fluids) is;

$\Delta T_{m=} \frac{\left(T_{o}-T_{c h w r}\right)-\left(T_{1}-T_{c h w s}\right)}{\ln \left(\left(T_{o}-T_{c h w r}\right) /\left(T_{1}-T_{c h w s}\right)\right)}$

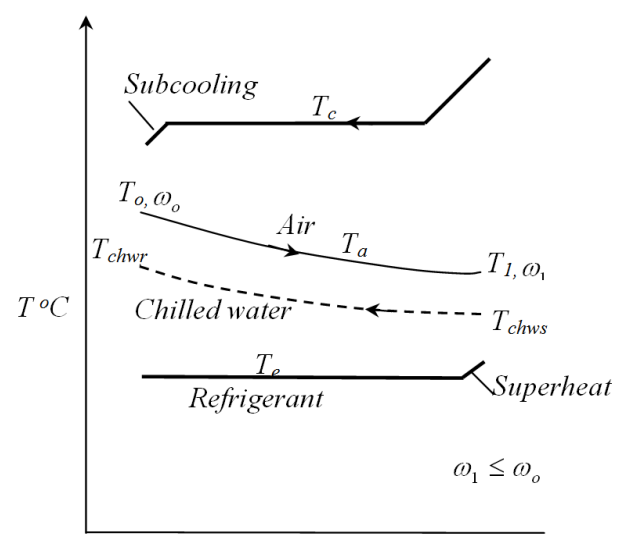

Fig. 2. Temperature levels for the three working fluids, not to scale

Equations 23 and 25 give the cooling coil cost as,

$$
C_{c c}^{c}=\beta_{c c}\left(\frac{\dot{Q}_{c c}}{U \Delta T_{m} F}\right)^{m}
$$

where, $\dot{Q}_{c c}$ is the thermal capacity of the cooling coil.

The atmospheric air enters at To and $\omega_{o}$ and leaves the cooling coil and enter the air compressor entrance at $T_{1}$ and ${ }^{\omega_{1}}$, as seen in Fig.1.a. Both $T_{1}$ and $\omega_{1}$ depend on the chilled water supply temperature (Tchws) and the chilled water mass flow rate $\dot{m}_{c w}$. When the outer surface temperature of the cooling coil falls below the dew point temperature (corresponding to the partial pressure of the water vapor) the water vapor condensates and leaves the air stream. This process may be treated as a cooling-dehumidification process as seen in Fig. 3. 
Steady state heat balance of the cooling coil gives $\dot{Q}_{c c}$ as;

$$
\begin{aligned}
\dot{Q}_{c c}= & \dot{m}_{a}\left(h_{o}-h_{1}\right)-\dot{m}_{w} h_{w}= \\
& \dot{m}_{c w} c_{p w} \varepsilon_{e f f, c c}\left(T_{c h w r}-T_{c h w s}\right)
\end{aligned}
$$

where, $\dot{m}_{c w}$ is the chilled water mass flow rate and $\dot{m}_{w}$ is the rate of water extraction from the air, $\dot{m}_{w}=\dot{m}_{a}\left(\omega_{o}-\omega_{1}\right)$. It (what it refers to?) is usually a small term when compared to the first and can be neglected, McQuiston et al. [33].

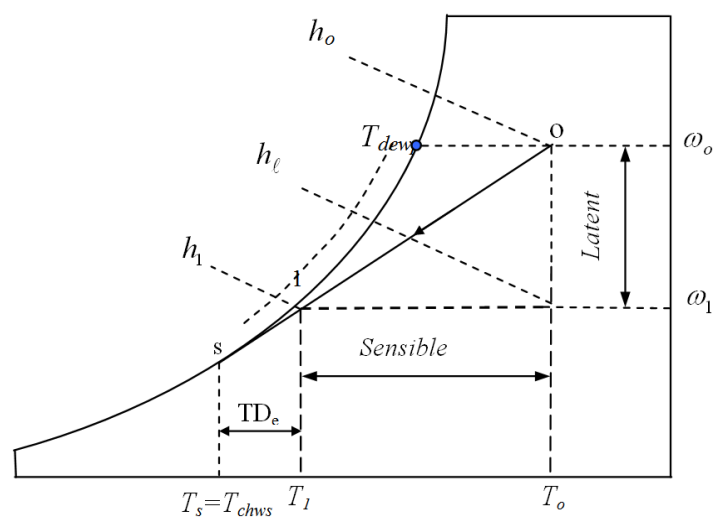

Fig. 3: Moist air cooling process on the psychrometric chart

In equation 28 , the enthalpy and temperature of the air leaving the cooling coil (h1 and T1) may be calculated from;

$$
C_{\text {total }}=\left\{\begin{array}{l}
a^{c}\left[\alpha_{c h}\left(1+\alpha_{m}\right) \dot{Q}_{e r}+\beta_{c c}\left(\frac{\dot{Q}_{e r} \times \varepsilon_{e f f, e r} \times \varepsilon_{e f f, c c}}{U \Delta T_{m} F}\right)^{m}\right]+ \\
t_{o p} \dot{Q}_{e r} C_{e l}\left[\left(\frac{1.1\left(T_{c}-T_{e}\right)}{T_{e}(1-\alpha x)^{n} \eta_{e u}}\right)+\left(\frac{\varepsilon_{e f f, e r} v_{f}(\Delta P)}{c_{p, w} \Delta T_{c h, w} \eta_{p u m p}}\right)\right]
\end{array}\right\}
$$

The first term in Eq. 33 is the annual fixed charges of the refrigeration machine and the surface air cooling coil, while the second term is the operation expenses that depend mainly on the electricity rate. The motor power has been increased by $10 \%$ to account for the auxiliaries' consumption. If the water pump's

$$
\begin{aligned}
& h_{1}=h_{o}-C F\left(h_{o}-h_{s}\right), \\
& T_{1}=T_{o}-C F\left(T_{o}-T_{s}\right),
\end{aligned}
$$

Where, CF is the contact factor of the cooling coil, defined as the ratio between the actual air temperature drop to the maximum, at which the air theatrically leaves at coil surface temperature $\mathrm{Ts}=$ Tchws and $100 \%$ relative humidity. Substituting for h1 from Eq. 29 into Eq. 28 gives

$$
\dot{Q}_{c c}=\dot{m}_{a}\left[C F\left(h_{o}-h_{c h w s}\right)-\left(\omega_{o}-\omega_{1}\right) h_{w}\right]
$$

Equations 25 and 31 yields;

$$
\dot{Q}_{e, r}=\frac{\dot{m}_{a}\left[C F\left(h_{o}-h_{c h w s}\right)-\left(\omega_{o}-\omega_{1}\right) h_{w}\right]}{\varepsilon_{e f f, e r} \times \varepsilon_{e f f, c c}}
$$

Equations 25, 31 and 32 give the cooling water flow rate, cooling coil capacity and the evaporator capacity in terms of the air mass flow rate and properties.

\subsection{Annual cost function}

Combining equations 24 and 25 and substituting for the cooling coil surface area, pump and auxiliary power gives the cost function in terms of the evaporator capacity $\dot{Q}_{e r}$, give the total annual cost as, power is considered small compared to the compressor power, the second term of the operation charges can be dropped. If the evaporator capacity $\dot{Q}_{e r}$ is replaced by the expression in Eq. 32, the cost function, in terms of the primary parameters, becomes; 


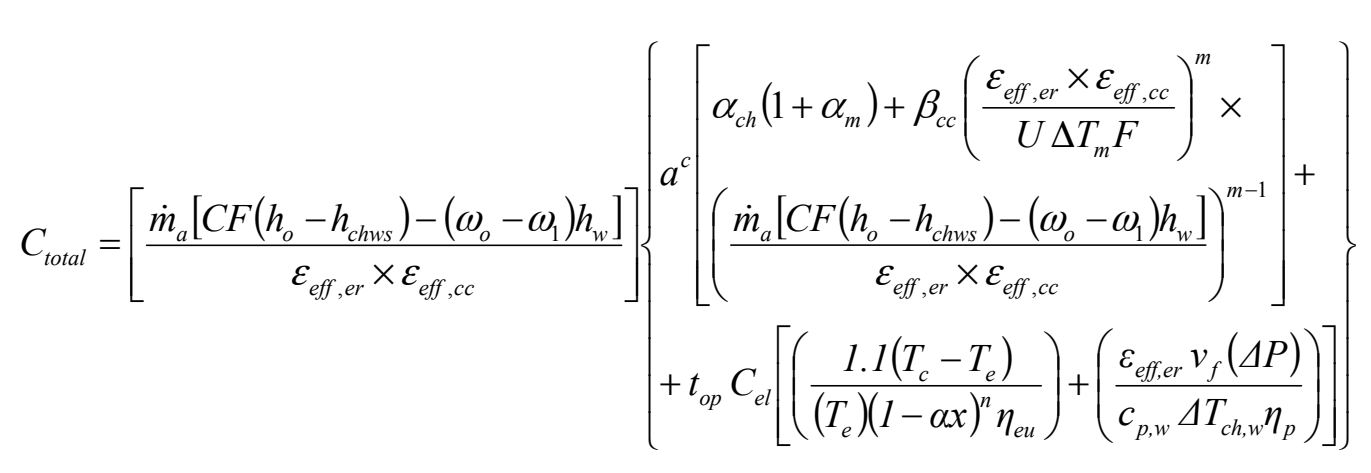

\section{EVALUATION CRITERIA OF GAS TURBINE COOLING SYSTEM}

In order to evaluate the feasibility of a cooling system coupled to a GT plant, the performance of the plant is examined with and without the cooling system. In general, the net power output of a complete system is:

$$
\dot{W}_{n e t}=\dot{W}_{t}-\left(\dot{W}_{c o m p}+\dot{W}_{e l, c h}\right)
$$

The three terms in Eq. 35 are functions of the air properties at the compressor intake conditions (T1 and $\left.\omega_{1}\right)$, which in turn depend on the performance of the cooling system. The present analysis considers the "power gain ratio" (PGR), a broad term suggested by AlHazmy et al. [8] that takes into account the operation parameters of the GT and the associated cooling system:

$$
P G R=\frac{\dot{W}_{\text {net,withcooling }}-\dot{W}_{\text {net,without cooling }}}{\dot{W}_{\text {net,without cooling }}} \times 100 \%
$$

For a stand-alone GT, PGR $=0$. Thus, PGR gives the percentage enhancement in power generation by the coupled system. The thermal efficiency of the system is an important parameter to describe the inputoutput relationship.

The thermal efficiency change factor (TEC) proposed in AlHazmy et al. [8] is defined as ,

$$
T E C=\frac{\eta_{c y, \text { with cooling }}-\eta_{c y, \text { without cooling }}}{\eta_{c y, \text { without cooling }}} \times 100 \%
$$

Both PGR and TEC can be easily employed to asses the changes in the system performance, but are not sufficient for a complete evaluation of the cooling method.

To investigate the economic feasibility of retrofitting a gas turbine plant with an intake cooling system, the total cost of the cooling system is determined (Eq. 33 or Eq. 34). The increase in the annual income cash flow from selling the additional electricity generation is also calculated. The annual energy electricity generation by the coupled power plant system is;

$$
E(\mathrm{kWh})=\int_{0}^{t_{o p}} \dot{W}_{n e t} d t
$$

If the gas turbine's annual electricity generation without a cooling system is Ewithout cooling and the cooling system increases the power generation to Ewith cooling, then the net increase in revenue due to the addition of the cooling system can be calculated from:

Net revenue $=\left(E_{\text {with cooling }}-E_{\text {without cooling }}\right) C_{\text {els }}(40)$

The profitability due to the coupled power plant system is defined as the increase in revenues due to the increase in electricity generation after deducting the expenses for installing and operating the cooling system as: 
Profitability $=$

$$
\text { ( } \left.E_{\text {with cooling }}-E_{\text {without cooling }}\right) C_{e l s}-C_{\text {total }}
$$

The first term in Eq. 41 gives the increase in revenue and the second term gives the annual expenses of the cooling system. The profitability could be either positive, which means an economical insensitive for adding the cooling system, or negative, meaning that there is not an economical advantage, despite the increase in the electricity generation of the plant.

\section{RESULTS AND DISCUSSION}

The performance of GT with a water chiller air cooling system and its economical feasibility are investigated. The selected site is the Industrial City of Yanbu (Latitude 240 $05^{\prime} \mathrm{N}$ and longitude $380 \mathrm{E}$ ) where a HITACH 700 model GT plant is already connected to the main electric grid. Table 1 lists the main specs of the selected GT plant. The water chiller capacity is selected on basis of the maximum annual ambient temperature. On August 18th, 2009, the dry bulb temperature (DBT) reached $50 \mathrm{oC}$ at $14: 00$ O'clock and the relative humidity was $84 \%$ at dawn time.

The recorded hourly variations in the DBT (To) and RHo are shown in Fig. 4 and the values listed in Table 2. Eq. 32 gives the evaporator capacity of the water chiller (Ton Refrigeration) as function of the DBT and RH. Fig. 5 shows that if the chiller is selected based on the maximum DBT $=50 \mathrm{oC}$ and RH $=18 \%$, (the data at 13: O'clock), its capacity would be 2200 Ton. Another option is to select the chiller capacity based on the air maximum $\mathrm{RH}(\mathrm{RH}=0.83$ and $\mathrm{To}=28.5 \mathrm{oC})$, which gives 3500 Ton.
It is more accurate, however, to determine the chiller capacity for the available climatic data of the selected day and determine the maximum required capacity, as seen in Fig. 6. For the weather conditions at Yanbu City, a chiller capacity of 4200 Ton is selected.

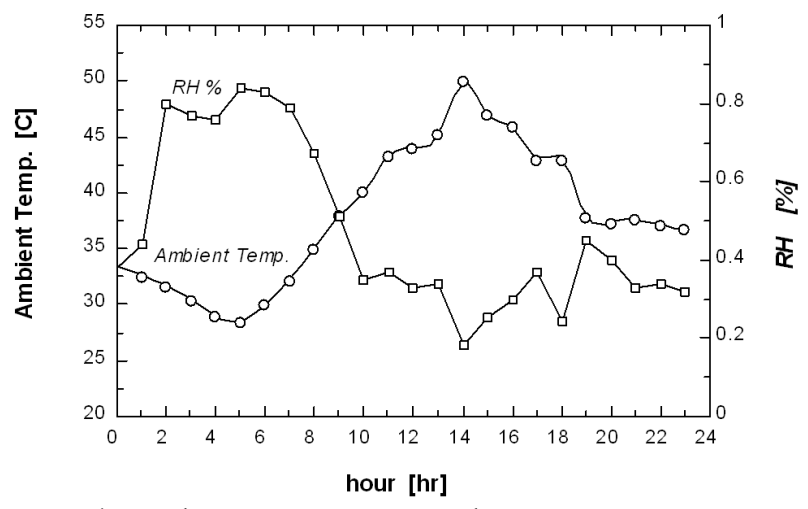

Fig. 4. Ambient temperature and $\mathrm{RH}$ variations on August 18th at Yanbu Industrial City, KSA

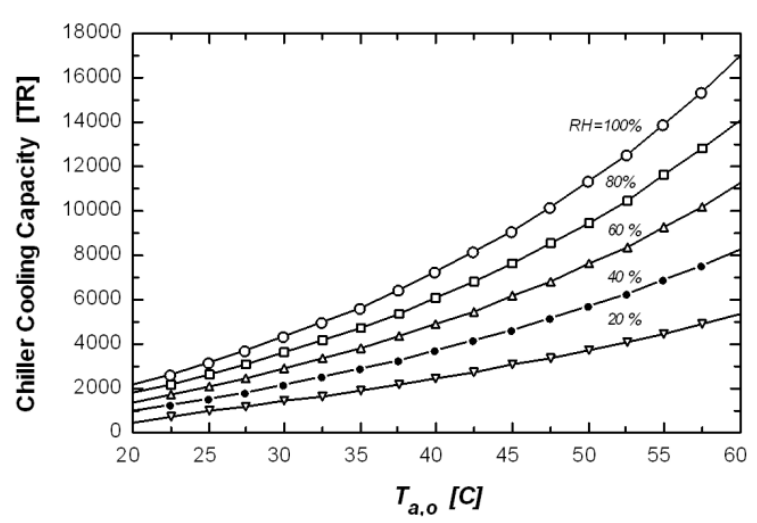

Fig. 5. Dependence of chiller cooling capacity on the climatic conditions

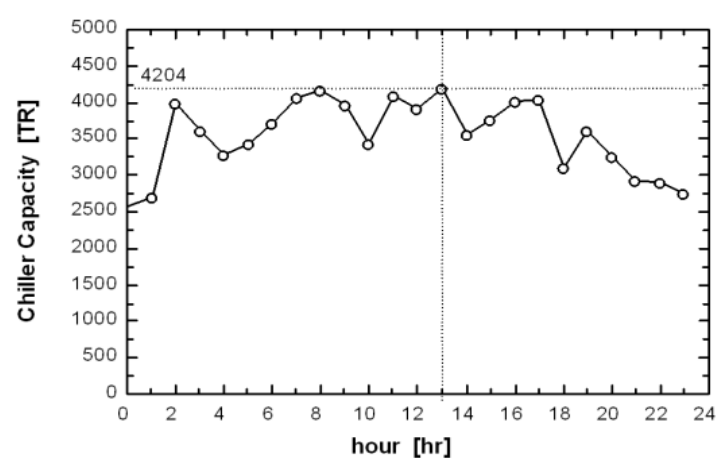

Fig. 6. Chiller capacity with the variation of the climatic conditions (temperature and $\mathrm{RH}$ ) 
TABLE 1: RANGE OF PARAMETERS FOR THE PRESENT ANALYSIS

\begin{tabular}{|c|c|}
\hline Parameter & Range \\
\hline \multicolumn{2}{|l|}{ Ambient air } \\
\hline Ambient air temperature, $T_{o}$ & $28-50^{\circ} \mathrm{C}$ \\
\hline Ambient air relative humidity, $R H_{o}$ & $18 \% \rightarrow 84 \%$ \\
\hline \multicolumn{2}{|c|}{ Gas Turbine, Model HITACH-700 } \\
\hline Pressure ratio, $P_{2} / P_{1}$ & 10 \\
\hline Turbine inlet temperature $T_{3}$ & $1273.15 \mathrm{~K}$ \\
\hline Volumetric air flow rate & $250 \mathrm{~m}^{3} \mathrm{~s}^{-1}$ at NPT \\
\hline Fuel net calorific value, $N C V$ & $46000 \mathrm{~kJ} \mathrm{~kg}^{-1}$ \\
\hline Turbine efficiency, $\eta_{t}$ & 0.88 \\
\hline Air Compressor efficiency $\eta_{c}$ & 0.82 \\
\hline Combustion efficiency $\eta_{\text {comb }}$ & 0.85 \\
\hline \multicolumn{2}{|l|}{ Generator } \\
\hline Electrical efficiency & $95 \%$ \\
\hline Mechanical efficiency & $90 \%$ \\
\hline \multicolumn{2}{|l|}{ Water Chiller } \\
\hline Refrigerant & R22 \\
\hline Evaporating temperature, $T_{e}$ & $T_{c h w s}-T D_{e}{ }^{\circ} \mathrm{C}$ \\
\hline Superheat & $10 \mathrm{~K}$ \\
\hline Condensing temperature, $T_{c}$ & $\mathrm{~T}_{\mathrm{o}}+\mathrm{TD}_{\mathrm{c}} \mathrm{K}$ \\
\hline $\begin{array}{l}\text { Condenser design temperature } \\
\text { difference } T D_{c}\end{array}$ & $10 \mathrm{~K}$ \\
\hline
\end{tabular}

TABLE 1: CONTINUED

\begin{tabular}{|c|c|}
\hline $\begin{array}{l}\text { Evaporator design temperature } \\
\text { difference TDe }\end{array}$ & $6 \mathrm{~K}$ \\
\hline Subcooling & $3 \mathrm{~K}$ \\
\hline $\begin{array}{l}\text { Chilled water supply temperature, } \\
T_{\text {chws }}\end{array}$ & $5^{\circ} \mathrm{C}$ \\
\hline $\begin{array}{l}\text { Chiller evaporator effectiveness, } \\
\varepsilon_{\text {eff }, e r}\end{array}$ & $85 \%$ \\
\hline $\begin{array}{l}\text { Chiller compressor energy use } \\
\text { efficiency, } \eta_{e u} \alpha_{c h}\end{array}$ & $\begin{array}{c}85 \% \\
172 \$ / k W\end{array}$ \\
\hline \multicolumn{2}{|l|}{ Cooling Coil } \\
\hline Cooling coil effectiveness $\boldsymbol{\varepsilon}_{e f f, c c}$ & $85 \%$ \\
\hline Contact Factor, CF & $50 \%$ \\
\hline \multicolumn{2}{|c|}{ Economics analysis } \\
\hline Interest rate $i$ & $10 \%$ \\
\hline $\begin{array}{l}\text { Period of repayment (Payback } \\
\text { period), } n\end{array}$ & 3 years \\
\hline The maintenance cost, $\alpha_{m}$ & $10 \%$ of $C_{c h}^{c}$ \\
\hline Electricity rate, $C_{e l}$ (Eqs. 33\&34) & $0.07 \$ / \mathrm{kWh}$ \\
\hline $\begin{array}{l}\text { Cost of selling excess electricity, } \\
C_{\text {els }} \text { (Eqs. 40\&41) }\end{array}$ & $0.07-0.15 \$ / \mathrm{kWh}$ \\
\hline Hours of operation per year, $t_{o p}$ & \\
\hline
\end{tabular}

TABLE 2: THE AMBIENT CONDITIONS AND THE COOLING COIL OUTLET TEMPERATURE AND HUMIDITY DURING $18^{\mathrm{TH}}$ AUGUST OPERATION

\begin{tabular}{|c|c|c|c|c|c|c|c|c|c|}
\hline Hour & $T_{o}^{o} \mathrm{C}$ & $R H$ & $T_{1}{ }^{\circ} \mathrm{C}$ & $R H_{1}$ & Hour & $T_{o}{ }^{o} \mathrm{C}$ & $R H$ & $T_{1}{ }^{\circ} \mathrm{C}$ & $R H_{1}$ \\
\hline 0 & 33.4 & 0.38 & 19.2 & 0.64 & 12 & 44.0 & 0.33 & 24.5 & 0.64 \\
\hline 1 & 32.6 & 0.44 & 18.8 & 0.70 & 13 & 45.2 & 0.34 & 25.1 & 0.66 \\
\hline 2 & 31.7 & 0.8 & 18.35 & 0.99 & 14 & 50.0 & 0.18 & 27.5 & 0.43 \\
\hline 3 & 30.5 & 0.77 & 17.75 & 0.98 & 15 & 47.0 & 0.25 & 26.0 & 0.53 \\
\hline 4 & 29.0 & 0.76 & 17.0 & 0.99 & 16 & 45.9 & 0.30 & 25.45 & 0.61 \\
\hline 5 & 28.5 & 0.84 & 16.75 & 0.97 & 17 & 43.0 & 0.37 & 24.0 & 0.69 \\
\hline 6 & 30.0 & 0.83 & 17.5 & 0.99 & 18 & 43.0 & 0.24 & 24.0 & 0.50 \\
\hline 7 & 32.2 & 0.79 & 18.6 & 0.96 & 19 & 37.9 & 0.45 & 21.45 & 0.76 \\
\hline 8 & 35.1 & 0.67 & 20.05 & 0.99 & 20 & 37.4 & 0.40 & 21.2 & 0.69 \\
\hline 9 & 38.0 & 0.51 & 21.5 & 0.84 & 21 & 37.6 & 0.33 & 21.3 & 0.60 \\
\hline 10 & 40.2 & 0.35 & 22.6 & 0.64 & 22 & 37.1 & 0.34 & 21.05 & 0.61 \\
\hline 11 & 43.3 & 0.37 & 24.15 & 0.69 & 23 & 36.8 & 0.32 & 20.90 & 0.58 \\
\hline
\end{tabular}


The hourly performance parameters of the GT plant, with and without cooling system (Eqs. 36 and 37), are calculated and compared. All thermo-physical properties are determined to the accuracy of the EES software (Klein and Alvarado [34]). The results show that the cooling system decrease the intake air temperature from To to T1 and increases the relative humidity to RH2 (Table 2). The chilled air temperature $\left(T_{1}\right)$ is calculated from equation 30, assuming 0.5 contact factor and a chilled water supply temperature of $5 \mathrm{oC}$. Using the data in Table 2, the solution of Equations 36 and 37 gives the daily variation in the PGR and TEC (Fig. 7). There is certainly a potential benefit of adding the cooling system when there is an increase in the power output all the time, the calculated average for the design days $12.25 \%$.

The PGR follows the same pattern of the ambient temperature, which simply means that the electric power of the GT plant increases during the hot hours of the day (10 $\mathrm{AM}$ to $18 \mathrm{PM}$ ), when electricity demand is high. The increase in the output power of the GT plant reaches a maximum of $15.46 \%$, with a little change in the plant thermal efficiency. The practical illustrative application indicates that a maximum decrease in the thermal efficiency change of only $0.223 \%$ occurs at 13:00 PM when the air temperature is $45.2 \mathrm{oC}$, and $\mathrm{RH}$ is $34 \%$.

Based on the daily variation of the ambient conditions on August 18th, assuming different values for selling the electricity (Cels), Equation 40 gives the hourly revenues needed to payback the investment after a specified operation period (selected by 3 years).

The different terms in both Equations 33 and 40 are calculated and presented in Fig. 8. First the effect of the climate changes is quite obvious on both the GT net power output as seen in Fig. 7 and on the total expenses as seen in Fig. 8.

The variations in $C_{\text {total }}$ are due to the changes in $\dot{Q}_{e v}$ in Eq. 33 that depends on $\left(T_{o}, T_{1}, \omega_{o}\right.$ and $\left.\omega_{1}\right)$. The revenues from selling additional electricity are also presented in the same Fig., which shows clearly the potential of adding the cooling system. A profitability of the system, being the difference between the total cost and the revenues, is realized when the selling rate of the excess electricity generation is higher than the base rate of $0.07 \$ / \mathrm{kWh}$.

Fig. 8 shows that selling the electricity to the consumers for the same price $\left(C_{e l s}=C_{e l}=\right.$ $0.07 \$ / \mathrm{kWh}$ ) makes the cooling system barley non-profitable during the morning and night time and during the hot hours of the day. This result is interesting and encourages the utilities to consider adding a time-of-use tariff during the high demand periods, which is customary the case in many courtiers.

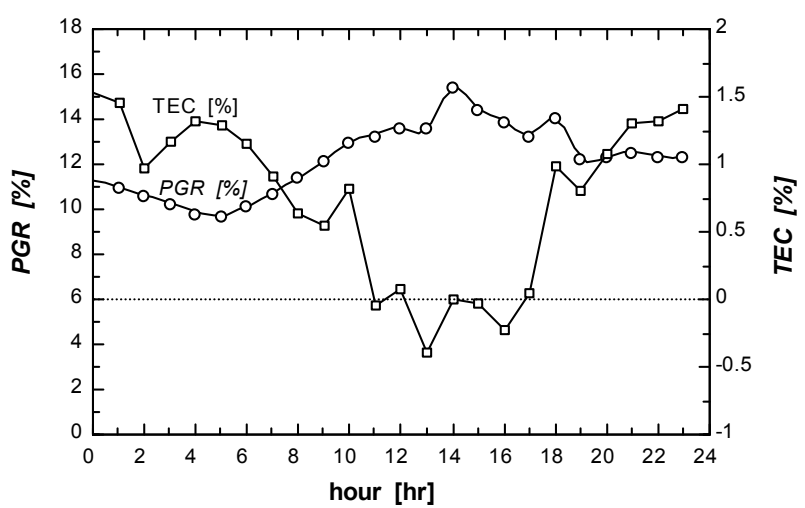

Fig. 7. Variation of gas turbine PGR and TEC during $18^{\text {th }}$ August operation

Should this become the case also in KSA, installing an air cooling system becomes economically feasible and profitable. Economics calculations for one year with 7240 operation hours and for different 
electricity rates $\left({ }^{C_{e l s}}\right)$ and fixed electricity rate $\left(C_{e l}=0.07 \$ / \mathrm{kWh}\right)$ are summarized in Table 3. The results in Table 3 show that there is always a net positive profit starting after the payback period for different energy selling prices.

During the first 3 years of the cooling system life, there is a net profit when the increase selling rate of the excess electricity generation to $0.15 \mathrm{~S} / \mathrm{kWh}$, nearly double the base tariff.

TABLE 3: ANNUAL NET PROFITS OUT OF RETROFITTING A COOLING SYSTEM TO A GT, HITACHI MS700 GT AT YANBU FOR DIFFERENT PRODUCT TARIFF AND 3 YEARS PAYBACK PERIOD

\begin{tabular}{|c|c|c|c|c|}
\hline $\begin{array}{c}\text { Electricity selling rate, } \\
C_{e l s}\end{array}$ & $\begin{array}{c}\text { Annuity-for chiller } \\
\text { and maintenance }\end{array}$ & $\begin{array}{c}\text { Annual operating } \\
\text { cost }\end{array}$ & $\begin{array}{c}\text { Annual net profit for the } \\
\text { first 3 years }\end{array}$ & $\begin{array}{c}\text { Annual net profit for the } \\
\text { fourth year }\end{array}$ \\
\hline$\$ / \mathrm{kWh}$ & $\$ / \mathrm{y}$ & $\$ / \mathrm{y}$ & $\$ / \mathrm{y}$ & $\$ / \mathrm{y}$ \\
\hline 0.07 & $1,154,780$ & $1,835,038$ & $-1,013,600$ & +141180 \\
\hline 0.1 & $1,154,780$ & $1,835,038$ & $-166,821$ & $+987,962$ \\
\hline 0.15 & $1,154,780$ & $1,835,038$ & $1,244,978$ & $+2,399,758$ \\
\hline
\end{tabular}

\section{CONCLUSIONS}

There are various methods to improve the performance of gas turbine power plants operating under hot ambient temperatures far from the ISO standards. One proven approach is to reduce the compressor intake temperature by installing an external cooling system. In this paper, a simulation model that consists of thermal analysis of a GT and coupled to and refrigeration cooler and economics evaluation is developed.

The performed analysis is based on coupling the thermodynamics parameters of the GT and cooler unit with the other variables as the interest rate, life time, increased revenue and profitability in a single cost function. The augmentation of the GT plant performance is characterized using the power gain ratio (PGR) and the thermal efficiency change term (TEC). The developed model is applied to a GT power plant in the city of Yanbu $\left(20^{\circ} 05^{\prime \prime} \mathrm{N}\right.$ latitude and 38o E longitude) KSA, where the maximum DBT has reached $50 \mathrm{oC}$ on August 18th, 2009. The recorded climate conditions on that day are selected for sizing out the chiller and cooling coil capacities. The performance analysis of the a GT, for a pressure ratio of 10 , rate of air intake of 250 $\mathrm{m} 3 / \mathrm{s}$ and $1000{ }^{\circ} \mathrm{C}$ maximum cycle temperature shows that the intake air temperature decreases by 12 and $22 \mathrm{~K}$, while the PGR increases a maximum of $15.46 \%$. The average

increase in the plant power output power is $12.25 \%$, with insignificant change in plant thermal efficiency.

In the present study, the profitability resulting from cooling the intake air is calculated for electricity rates between 0.07 and $0.15 \$ / \mathrm{kWh}$ and a payback period of 3 years. Cash flow analysis of the GT power plant in the city of Yanbu shows a potential for increasing the output power of the plant and increased revenues. The profitability as a result of adding the cooling system increase as the electricity rate increase during the peak demand periods, beyond the current base rate of $0.07 \$ / \mathrm{kWh}$.

\section{NOMENCLATURES}

$A_{c c} \quad$ Cooling coil heat transfer area, $\mathrm{m}^{2}$

$C_{c c}^{c} \quad$ capital cost of cooling coil (\$) 


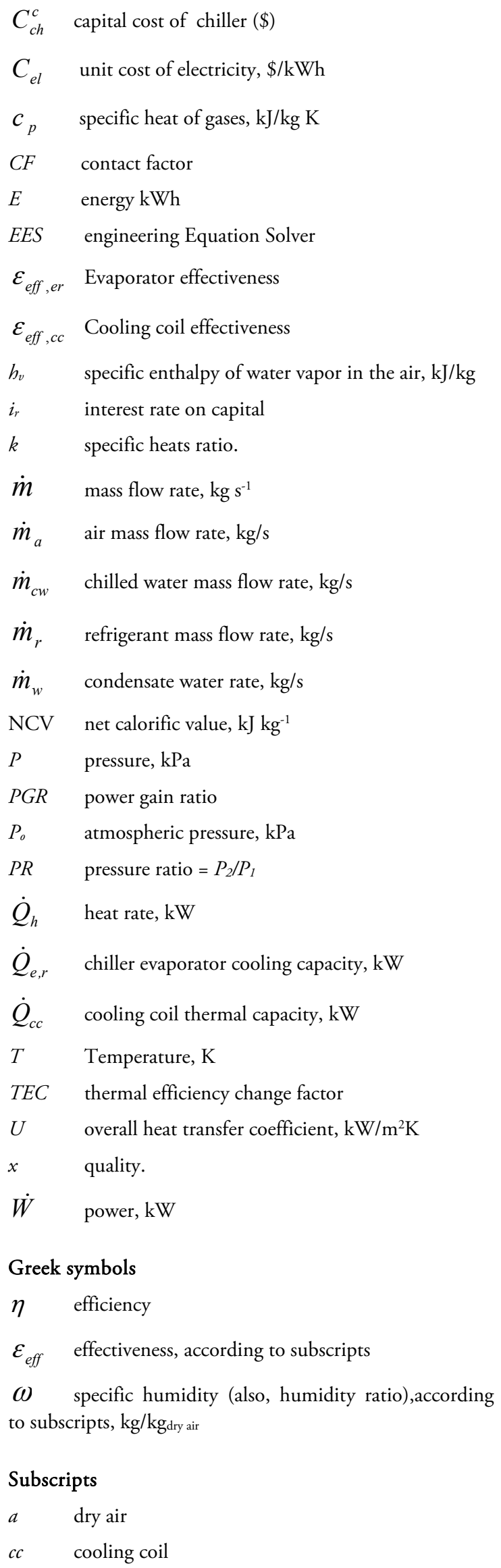

\section{Subscripts}

a dry air

cc cooling coil

$\begin{array}{ll}\text { ch } & \text { chiller } \\ \text { comb } & \text { combustion } \\ \text { comp } & \text { compressor } \\ e l & \text { electricity } \\ f & \text { fuel } \\ g & \text { gas } \\ o & \text { ambient } \\ t & \text { turbine } \\ v & \text { vapor }\end{array}$

\section{REFERENCES}

[1] Elliot J. 2001. Chilled air takes weather out of equation, Diesel and gas turbine world wide, Oct: 49-96.

[2] Cortes CPE, Williams D. 2003. Gas turbine inlet cooling techniques: An overview of current technology. Proceedings Power GEN 2003, Las Vegas Nevada Dec. 9-11.

[3] Wang T, Li X and Pinniti V. 2009. Simulation of mist transport for gas turbine inlet air-cooling. ASME Int. Mec. Eng congress, November 13-19. Anaheim, Ca, USA,

[4] Ameri M, Nabati H. Keshtgar A. 2004. Gas turbine power augmentation using fog inlet cooling system. Proceedings ESDA04 7th Biennial conf. engineering systems design and analysis, Manchester UK. paper ESDA 200458101.

[5] Ameri M, Shahbazian HR, Nabizadeh M. 2007. Comparison of evaporative inlet air cooling systems to enhance the gas turbine generated power. Int. J. Energy Res. 31: 483-503.

[6] Jonsson M, Yan J. 2005. Humidified gas turbines- A review of proposed and implemented cycles, Energy 30: 1013-1078.

[7] Alhazmy MM. and Najjar YS. 2004. Augmentation of gas turbine performance using air coolers, App. Thermal Engineering. 24: 415429.

[8] Alhazmy MM, Jassim RK, Zaki GM. 2006. Performance enhancement of gas turbines by inlet air-cooling in hot and humid climates. International Journal of Energy Research 30:777797.

[9] Sanaye S, Tahani M. 2010. Analysis of gas turbine operating parameters with inlet fogging and wet compression processes, Applied thermal engineering, 30: 234-244.

[10] Tillman TC, Blacklund DW, Penton JD. 2005. Analyzing the potential for condensate carry-over from a gas cooling turbine inlet cooling coil, 
ASHRAE Transactions 111 (Part 2) DE-05-6-3: 555-563.

[11] Chaker M., Meher-Homji, CB, Mee M. 2002. Inlet fogging of gas turbine engines - Part B: Fog droplet sizing analysis, nozzle types, measurement and testing, ASME Proceedings of Turbo Expo 2002, 4:429-442.

[12] Chaker, M, Meher-Homji CB, Mee M. 2002. Inlet fogging of gas turbine engines - part c: fog behavior in inlet ducts, cfd analysis and wind tunnel experiments, ASME Proceedings of Turbo Expo 2002, Vol. 4:443-455.

[13] Chaker M, Meher-Homji CB, Mee III, Nicholson A. 2003. Inlet fogging of gas turbine engines detailed climatic analysis of gas turbine evaporation cooling potential in the USA. J Eng Gas Turbine Power 125(1):300-309.

[14] Homji-Meher, BC, Mee T, Thomas R. 2002. Inlet fogging of gas turbine engines, part $\mathrm{B}$ : Droplet sizing analysis nozzle types, measurement and testing, Proceedings of the ASME Turbo Expo 2002, Amsterdam, Netherlands, June 2002 paper No: GT-30563.

[15] Gajjar H, Chaker M. 2003. Inlet fogging for a 655 MW combined cycle power plant-design, implementation and operating experience, ASME Proceedings of Turbo Expo 2003, Vol. 2:853860.

[16] Yang C, Yang Z, Cai R. 2009. Analytical method for evaluation of gas turbine inlet air cooling in combined cycle power plant, Applied Energy 86:848-856

[17] Ondrays IS, Wilson DA, Kawamoto N, Haub GL. 1991. Options in gas turbine power augmentation using inlet air chilling. Eng. Gas Turbine and Power. 113: 203-211.

[18] Punwani D, Pierson T, Sanchez C, Ryan W. 1999. Combustion turbine inlet air cooling using absorption chillers some technical and economical analysis and case summaries ASHRAE Annual Meeting, Seattle, Washington, June, 99.

[19] Kakarus E, Doukelis A, Karellas S. 2004. Compressor intake air cooling in gas turbine plants. Energy 29:2347-2358.

[20] Stewart W, Patrick A. 2000. Air temperature depression and potential icing at the inlet of stationary combustion turbines. ASHRAE Transactions 106, pt 2:318-327.
[21] Farzaneh-Gord M and Deymi-Dashtebayaz M. 2009. A new approach for enhancing performance of a gas turbine (case study: Khangiran refinery). Applied Energy 86: 27502759

[22] Zaki GM, Jassim RK, Alhazmy MM. 2007. Brayton refrigeration Cycle for gas turbine inlet air cooling, International Journal of Energy Research 31:1292-1306.

[23] Jassim RK., Zaki GM., Alhazmy MM., "Energy and Exergy Analysis of Reverse Brayton Refrigerator for Gas Turbine Power Boosting” Int. Journal of Exergy, Vol. 6 , No 2 pp 143-165 (2009).

[24] Khan JR, Lear WE, Sherif SA, Crittenden JF. 2008. Performance of a novel combined cooling and power gas turbine with water harvesting. ASME Journal of Engineering for Gas Turbines and Power 130 (4).

[25] Erickson DC. 2003. Aqua absorption turbine inlet cooling, Proceedings of IMEC 03, ASME International Mechanical Engineering Congress \& Exposition, Nov. 16-21, Washington DC

[26] Erickson DC. 2005. Power fogger cycle. ASHRAE Transactions 111, part 2:551-554.

[27] Gareta R, Romeo LM, Gil A. 2004. Methodology for the economic evaluation of gas turbine air cooling systems in combined cycle applications Energy 29:1805-1818.

[28] Hasnain SM, Alawaji SH, Al-Ibrahim AM, Smiai MS. 2000. Prospects of cool thermal storage utilization in Saudi Arabia. Energy Conversion \& Management 41: 1829-1839.

[29] Dossat RJ. 1997. Principles of Refrigeration, John Wiley and Sons, NY.

[30] Cleland AJ, Cleland DJ, White SD. 2000. CostEffective Refrigeration, Short course notes, Institute of Technology and Engineering, Massey University, New Zealand

[31] Kotas TJ. 1995. The exergy method of thermal plant analysis, Krieger, Malabar, Florida, USA.

[32] Hameed Zubair, Personal communication, Salem York Co. Saudi Arabia

[33] McQuiston FC, Parker JD, Spilter JD. 2005. Heating, Ventilating and Air conditioning: Design and analysis, 6th edition, John Wily, NY.

[34] Klein KA, Alvarado FL. 2004. EES-Engineering Equation Solver, Version 6.648 ND, F-Chart Software, Middleton, WI. 


\title{
التحليل الحراري-الإقتصادي لمحطات التوربينات الغازية مع تبريد الهواء الداخل
}

\author{
رحيم جاسم'، جلال زكي و و ماجد الحازمي

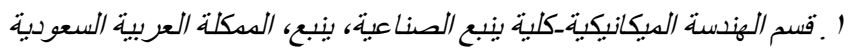

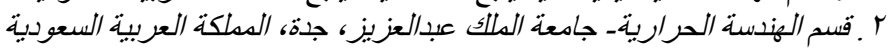

الملخص:

تعاني محطات التوربينات الغازية التي تعمل في المناطق الجافة من نقصان القدرة الناتجة خلال أثشر الصيف الحارة بسبب نقص التبريد. وللتظلب على هذه المعضلة يتم تبريد الهواء الداخل للضاغط. أن التحليل الحراري لدورة بريتون المرتبطة مع دورة التبريد أظهر زيادة واعدة في القدرة الناتجة مع نقصان طفيف بالكفاءة الحر ارية. لقد تم تطوير نموذج لتطبيقية على دورة مفتوحة لمحطة توربينات غازية في مدينة ينبع الصناعية على ساحل البحر الأحمر وقد أظهرت نتائج هذه الدراسة إن التحسن في القدرة الناتجة بعتمد على درجة تبريد الهواء الداخل للضاغط. ولحالة الدراسة هذه، فقد وجد أن نسبة الكسب القصوى للطاقة بلغت 7 إع 10 مع نقصان

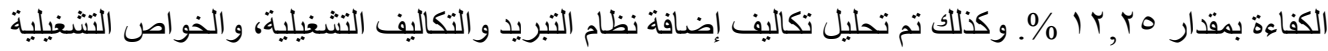
للتوربين الغازي ولنظام التبريد عند عوامل مختلفة مثل معدل الفائدة، والعمر التثغيلي، وتكاليف التثغيل و الصيانة. ونم حساب الفائدة الناتجة عن إضافة نظام التبريد عند أسعار مختلفة للكهرباء. 